Байкальский государственный университет, 2. Иркутск, Российская Федеращия

К. С. Черёмухина

Байкальский государственный университет, 2. Иркутск, Российская Федерация

\title{
МЕЖКУЛЬТУРНАЯ КОМПЕТЕНТНОСТЬ КАК НЕОБХОДИМАЯ СОСТАВЛЯЮЩАЯ ПРОФЕССИОНАЛЬНОЙ ПОДГОТОВКИ ЮРИСТОВ
}

\begin{abstract}
АНнОтАЦИЯ. В статье уточняется понятие межкультурной компетентности, представлена исследовательски проверенная скорректированная структурная модель межкультурной компетентности, включающая в себя четыре основных компонента: Толерантность; Этническая идентичность (этническое самосознание); Перцептивно-коммуникативная компетентность; Апперцептивный компонент. Кроме того, обосновывается необходимость включения межкультурной компетентности в психограмму юриста, что расширит его профессиональные возможности, будет способствовать формированию психологической безопасности и сохранению психического здоровья. Качественное образование предполагает подготовку выпускника способного к профессиональной мобильности, готового действовать в различных профессиональных ситуациях, обладающего навыками эффективного взаимодействия с коллегами, партнерами, клиентами. Поэтому в выборку исследования вошли студенты юридического института Байкальского государственного университета. Полученные данные позволяют говорить о диссонансе: с одной стороны, толерантность рассматривается респондентами как норма, в том числе применительно к будущей профессиональной идентичности, они обладают достаточными перцептивно-невербальными навыками, с другой стороны, выявлено, что доминирующей коммуникативной установкой является жестокость в отношении других, что также распространяется на тех людей, с которыми потенциально придется общаться в профессиональной деятельности, обнаружен низкий уровень произвольного управления своими эмоциями. Данное противоречие может стать причиной серьезных профессиональных деформаций.

кЛЮчЕВЫЕ сЛОВА. Межкультурная компетентность; толерантность; этническая толерантность; факторы межкультурной компетентности; коммуникативная толерантность; профессиональная подготовка юристов; психологическая безопасность. ИНФОРМАЦИЯ О СТАТЬЕ. Дата поступления 10 мая 2017 г.; дата принятия к печати 25 мая 2017 г.; дата онлайн-размещения 23 июня 2017 г.
\end{abstract}

E. L. Trofimova Baikal State University, Irkutsk, Russian Federation

K. S. Cheremukhina Baikal State University, Irkutsk, Russian Federation

\section{CROSS-CULTURAL COMPETENCE AS A NECESSARY CONSTITUENT OF PROFESSIONAL TRAINING LAWYERS}

ABSTRACT. The article specifies the concept of the cross-cultural competence, presents a research-tested corrected structural model of the intercultural competence that includes four main components: Tolerance; Ethnic Identity (ethnic self-consciousness); Perceptive-Communicative Competence: Apperceptive Component. Besides, it substantiates the necessity of including the cross-cultural competence into lawyer's

(C) Е. Л. Трофимова, К. С. Черемухина, 2017

\section{Baikal Research Journal}

электронный научный журнал Байкальского государственного университета 
psychogram, which will expand his professional opportunities, will contribute to developing psychological security and maintaining psychological health. High-quality education assumes training the graduate capable of professional mobility, ready to act in various professional situation, possessing skills to communicate effectively with colleges, partners and clients. That is why, the research selection includes students of the Law Institute of Baikal State University. The results obtained allow to speak about a dissonance: on the one hand, tolerance is regarded by respondents as a norm, among other things in the context of the future professional identity, and they possess sufficient perceptive-non-verbal skills; on the other hand, it reveals the fact that of dominating communicative directive is cruelty in regard of others, which is also expanded to those people to be potentially in contact in professional activity. This contradiction can cause serious professional deformations.

KEYWORDS. Cross-cultural competence; tolerance; ethnic tolerance; factors of cross-cultural competence; communicative tolerance; professional training lawyers; psychological security.

ARTICLE INFO. Received May 10, 2017; accepted May 25, 2017; available online June 23, 2017.

Обучение в вузе является одним из основных этапов профессионального становления. Студент в рамках образовательного процесса должен овладеть не только узконаправленными знаниями и умениями, но и приобрести личностные и профессионально важные качества. Круг профессионального общения специалиста в области юриспруденции потенциально очень широк, что также предполагает овладение навыками эффективного взаимодействия, умения преодолевать барьеры в общении, конструктивно разрешать конфликты. Коммуникативная компетентность отражена в профессионально обусловленной структуре личности юриста, в психограмму включены такие качества как: «внимательное и доброжелательное отношение к людям, умение слушать партнера по диалогу, эмпатийность»» и др. [1].

Образовательное пространство вуза, профессиональная деятельность являются активными зонами межэтнических, межкультурных и межконфессиональных контактов, в результате которых у многих студентов закрепляются стереотипы межэтнического, межкультурного и межконфессионального восприятия и поведения; формируется система ценностей и установок. В соответствии с Федеральным государственным образовательным стандартом высшего образования (ФГОС ВО) профессиональная подготовка юристов должна предусматривать овладение ими таких компетенций, как: способность к коммуникации в устной и письменной формах на русском и иностранном языках для решения задач межличностного и межкультурного взаимодействия (ОК-5); способность работать в коллективе, толерантно воспринимая социальные, этнические, конфессиональные и культурные различия (ОК-6) (ФГОС ВО по направлению подготовки 40.03.01 Юриспруденция (уровень бакалавриата)). Помогая студентам, обучающимся на юридических специальностях, овладеть данными компетенциями, мы, тем самым, формируем умения и навыки вести диалог и выстраивать взаимоотношения с представителями разных этнических групп, разных культур, разных конфессий, т. е. сформировать межкультурную компетентность.

Межкультурная компетентность, на наш взгляд, может рассматриваться как одно из условий формирования профессиональной и психологической безопасности будущего специалиста в юридической профессии. Юридическое направление традиционно сохраняет свою популярность у абитуриентов. Одним из мотивов выбора профессии является ожидаемый статус юриста в обществе, что воспринимается как гарант защищенности, и особую актуальность данные установки приобретают в периоды нестабильности, кризиса. Однако не все абитуриенты и в последующем студенты осознают, что профессия юриста, как и многие другие

\section{Baikal Research Journal}

электронный научный журнал Байкальского государственного университета 
профессии, накладывает свои ограничения, имеет зоны риска, угроз, опасности и даже задает определенную виктимность. Готовность понять психологические особенности, логику представителя другой культуры важно как с точки зрения профессиональных задач, так и с позиции психологической безопасности личности юриста, согласования профессиональных, гражданских, этнических, нравственных взглядов, сохранения его психологического здоровья.

Под межкультурной компетентностью мы понимаем совокупность знаний, умений, навыков, позволяющих индивиду вступать в успешные, эффективные контакты с представителями других культур, әффективно и долговременно сотрудничать, общаться и совместно работать [2-5].

Анализ научной литературы позволяет судить о многоплановости исследований посвященных различным аспектам межкультурной компетенции, отраженных в трудах отечественных авторов: Н. Н. Васильева, А. Д. Карнышев, А. С. Купавская, О. А. Леонтович, А. В. Новицкая, Т. В. Поштарева, А. П. Садохин, Г. У. Солдатова, А. В. Макарчук, О. Б. Большакова и Т. А. Терехова, Е. Л. Трофимова и др.; [6-13] и зарубежных исследователей: М. Беннет, Г. Чен, К. Кнапп, Г. Фишер и др.[14-17]. Среди иркутских исследователей следует отметить работы А.Д. Карнышева, Т. А. Тереховой, Е. Л. Трофимовой и др. [2-5; 16-19].

Особое внимание уделяется разработки моделей межкультурной компетентности, так среди отечественных исследователей разработкой моделей занимались Г. В. Елизарова, А. Д. Карнышев, А. С. Купавская, В. И. Наролина, И. Ф. Птицына, А. П. Садохин, Т. А. Терехова и др. [16; 20-21]. Из работ зарубежных ученых следует отметить модель глобальных компетенций Хэмилтоном (Hamilton), Ричардсоном (Richardson) и Шуфондом (Shufond), модель Д. Дердорффа (Deardorff), модель пересекающихся мировоззренческих установок А. Фантини (Fantini), спектральную модель Б. Купки (Kupka), модель межкультурной сензитивности M. Беннетта (Bennett), причинно-следственную (каузальную) модель Тинг-Туми (Ting-Toomey) и Куроги (Kurogi), модель Дж. Гуллахорна и др. [14-17].

В результате того, что межкультурная компетентность является объектом исследований психологов, педагогов, философов, культурологов, историков, антропологов, этнографосоциологов; она имеет междисциплинарный статус проблемы.

Анализ изученных источников позволил нам выделить следующие компоненты в структуре межкультурной компетентности:

1. Когнитивный компонент, в который мы включили: знания о собственной и иной культурах (обычаи, ценности, нормы, правила, распределение ролей и т. д.); представления о сходствах и различиях своей и иной культур и осознание значимости культурных различий; знания, способствующие адекватному кодированию и декодированию невербальных сообщений от представителей иной культуры.

2. Аффективный компонент, содержащий: доброжелательное отношение к представителям другой культуры; эмпатийное отношение к представителям другой культуры; толерантное отношение к представителям другой культуры; эмоциональную стабильность в межкультурных взаимоотношениях.

3. Мотивационный компонент, включающий: потребность в межкультурной коммуникации; потребность в получении знаний об иной культуре (интерес); потребность, желание общения с «иными» (коммуникативные установки); готовность проявлять эмпатию к представителям иной культуры; готовность к межэтническим контактам; высокий уровень аттракции к представителям.

4. Поведенческий компонент: способность адаптироваться к разным культурам; способность контролировать эмоциональные реакции, связанные с различиями в культурах; способность проявлять культурную эмпатию, способность быть толерантным.

\section{Baikal Research Journal}

электронный научный журнал Байкальского государственного университета 
В соответствии с этой моделью были подобраны методики (табл. 1).

Соответствие диагностического инструментария компонентам

\begin{tabular}{|l|l|}
\hline \multicolumn{1}{|c|}{ Компоненты } & \multicolumn{1}{|c|}{ Методики } \\
\hline Когнитивный & $\begin{array}{l}\text { Теоретический тест } \\
\text { Семантический дифреренциал } \\
\text { Методика «Виды и компоненты толерантности и интолерантности» } \\
\text { (когнитивный компонент) } \\
\text { Методика «Виды и компоненты толерантности и интолерантности» } \\
\text { (идентификационно-групповой компонент) }\end{array}$ \\
\hline Аффективный & $\begin{array}{l}\text { Диагностика доброжелательности (по шкале Кэмпбелла) } \\
\text { Диагностика «эмоционального интеллекта» (Н. Холл) - шкала «эмпатия» } \\
\text { Методика «Виды и компоненты толерантности и интолерантности» (аф- } \\
\text { Мективный компонент) } \\
\text { Мотивационный } \\
\text { Управлять своими эмоциями» } \\
\text { Методика «Коммуникативная установка» (В. В. Бойко) } \\
\text { Методика «Виды и компоненты толерантности и интолерантности» (моти- } \\
\text { вационно-потребностный компонент) } \\
\text { Методика «Типы этнической идентичности» (Г. У. Солдатова) }\end{array}$ \\
\hline & $\begin{array}{l}\text { Методика «Виды и компоненты толерантности и интолерантности» } \\
\text { (деятельностно-стилевой компонент) } \\
\text { Методика «Виды и компоненты толерантности и интолерантности» (кона- } \\
\text { тивный компонент) } \\
\text { Тест коммуникативных умений (л. Михельсон) } \\
\text { Методика определения уровня перцептивно-невербальной компетентности } \\
\text { (Г. Я. Розен) }\end{array}$ \\
\hline
\end{tabular}

Целью исследования стало выявление уровня межкультурной компетентности и составляющих ее компонентов у студентов. В исследовании приняли участие 200 студентов юридического института Байкальского государственного университета в возрасте 16-22 лет; из них женского пола -128 , мужского $-72 ; 40-$ бурят, 160 - русские.

Данные, полученные по методике «Виды и компоненты толерантности-интолерантности» (ВИКТИ), представлены в табл. 2. Из данной методики мы использовали лишь часть компонентов, которые преимущественно связаны, на наш взгляд, с межкультурной компетентностью.

Комментируя табл. 2 , отметим, что в целом по выборке преобладает средний уровень толерантности. В диапазон высоких значений по видам толерантности у студентов попадают толерантные установки по отношению к другому полу, в межличностных взаимоотношениях, к представителям другого поколения. Относительно самые низкие показатели по шкале толерантности $\kappa$ другому этносу. Сопоставление результатов с нашими предыдущими исследованиями показывает, что сохраняется общая тенденция: более высокие значения студенты демонстрируют в отношении гендерной и межличностной толерантности, а относительно самый низкий вид толерантности: межэтническая. В структуре компонентов толерантности высокий диапазон значений не зафиксирован, на уровне средних показателей выражены этико-нормативный (толерантность как норма) и идентификационно-личностный компоненты, на границе низких значений оказался идентификационно-групповой компонент, то есть толерантность базируется, прежде всего, на личностной самоидентификации и декларируется преимущественно на уровне установки, нормы, возможно, это можно интерпретировать как осознание своей профессиональной роли, которая предъявляет требования непредвзятого отношения к представителям любых социальных групп.

\section{Baikal Research Journal}


Средние показатели, полученные по результатам методики "Виды и колпоненты толерантности-интолерантности"

\begin{tabular}{|l|r|}
\hline \multicolumn{1}{|c|}{ Виды и компоненты толерантности } & Средние показатели по выборке \\
\hline Другое поколение & 50,395 \\
\hline Другой пол & 54,300 \\
\hline Отношения с другими & 52,540 \\
\hline Другой этнос & 46,245 \\
\hline Другая культура & 49,195 \\
\hline Другая вера & 49,175 \\
\hline Толерантность & 50,130 \\
\hline Аффективный компонент & 37,870 \\
\hline Когнитивный компонент & 35,980 \\
\hline Конативный компонент & 36,015 \\
\hline Потребностно-мотивационный компонент & 34,430 \\
\hline Деятельностно-стилевой компонент & 32,025 \\
\hline Этико-нормативный компонент & 38,770 \\
\hline Ценностно-ориентационный компонент & 33,800 \\
\hline Личностно-смысловой компонент & 35,030 \\
\hline Идентификационно-групповой компонент & 29,270 \\
\hline Идентификационно-личностный компонент & 38,790 \\
\hline
\end{tabular}

Среди типов этнической идентификации опрошенных, как видно из рис. 1 , доминирует позитивная этническая идентичность (норма).

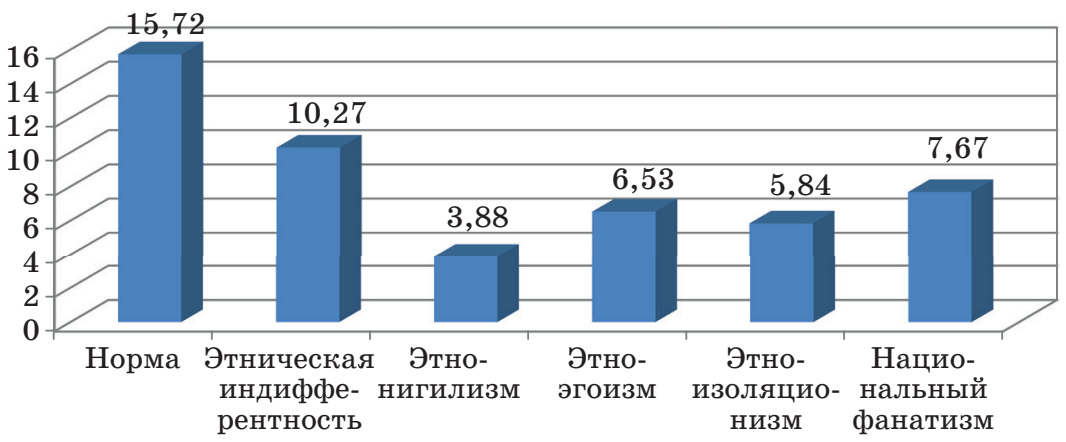

Рис. 1. Типы этнической идентичности

Этот тип характеризуется высокой толерантностью и готовностью к межэтническим контактам, сочетанием позитивного отношения к собственному народу с позитивным отношением к другим народам. В полиэтническом обществе позитивная этническая идентичность имеет характер нормы и свойственна подавляющему большинству. Она задает такой оптимальный баланс толерантности по отношению к собственной и другим этническим группам, который позволяет рассматривать ее, с одной стороны, как условие самостоятельности и стабильного существования этнической группы, с другой - как условие мирного межкультурного взаимодействия в полиэтническом мире.

На втором месте обозначился тип этнической идентичности - «Этническая индифферентность», что может говорить о размывании этнической идентичности, выраженном в неопределенности этнической принадлежности, неактуальности этничности $(10,27)$. Возможно, такие респонденты более склонны проявлять толерантное отношение по отношению к иноэтничному окружению. На это могут повлиять и многонациональность общества и другие причины.

\section{Baikal Research Journal}

электронный научный журнал Байкальского государственного университета 
В интервале средних значений от 7,67 до 5,84 по общей выборке находятся национальный фанатизм $(7,67)$, этноэгоизм $(6,53)$ и этноизоляционизм $(5,84)$.

Самые низкие показатели среднего значения у типа «Этнонигилизм» - данный тип этнической идентичности может выражаться в безобидной форме на вербальном уровне как результат восприятия через призму конструкта "мой народ», но может предполагать, например, напряженность и раздражение в общении с представителями других этнических групп или признание за своим народом права решать проблемы за «чужой» счет.

Проявления различных типов этнической идентичности по половой принадлежности респондентов значимых различий не имеют.

По результатам методики на определение уровня перцептивно-невербальной компетентности (Г. Я. Розен) можно сделать следующие выводы: уровень выше среднего диагностируется у 51 \% (или 102 опрошенных), средний - у 49 \% (98 человек), низкий - не зафиксирован. Таким образом, в целом выборка характеризуется умеренным уровнем перцептивно-невербальной компетентности, возможно, это связано с тем, что данные студенты находятся в своей культурной среде и чувствуют себя комфортно. Для студентов с высоким уровнем перцептивно-невербальной компетентности скорее характерна поглощенность проблемами окружающих людей и некоторое пренебрежение собственными, когда как для респондентов с низким уровнем перцептивно-невербальной компетентности присуще обратное. Это может стать препятствием к налаживанию конструктивных межличностных взаимоотношений. Наиболее предпочтительным для гармоничного развития личности, комфортного самочувствия и конструктивного взаимодействия с окружающими людьми является средний уровень перцептивно-невербальной компетентности.

Данные теста коммуникативных умений Л. Михельсона (перевод и апробация Ю. 3. Гильбуха) показывают, что респонденты преимущественно демонстрируют компетентное уверенное поведение (средний балл 18,035$)$, ориентации на агрессивное (средний балл - 3,065) и зависимое от других поведение (средний балл $5,89)$ выражены слабо.

Результаты по методике В. В. Бойко «Коммуникативная установка» представлены в табл. 3.

Таблица 3

Выраженность коммуникативных установок

\begin{tabular}{|l|r|r|}
\hline \multicolumn{1}{|c|}{ Коммуникативная установка } & $\begin{array}{c}\text { Максимальный } \\
\text { балл }\end{array}$ & $\begin{array}{c}\text { Cредний балл } \\
\text { по выборке }\end{array}$ \\
\hline $\begin{array}{l}\text { Завуалированная жестокость в отношениях к людям, в су- } \\
\text { ждениях о них }\end{array}$ & 20 & 15,27 \\
\hline Открытая жестокость в отношениях к людям & 45 & 25,45 \\
\hline Обоснованный негативизм в суждениях о людях & 5 & 2,32 \\
\hline Брюзжание & 10 & 4,28 \\
\hline Негативный личный опыт общения с окружающими & 20 & 8,91 \\
\hline
\end{tabular}

У большинства респондентов по шкале «Завуалированная жестокость в отношениях к людям, в суждениях о них» показатель выше среднего (только 4 \% опрошенных дали ответы в диапазоне низких значений), это говорит о том, что в замаскированной, приглушенной или косвенной форме суждения студентов характеризуются недоброжелательностью, настороженностью в отношениях со многими партнерами, нежеланием откликаться на их проблемы. $67 \%$ испытуемых на уровне выше среднего и высоком склонны проявлять открытую жестокость в отношениях к другим людям. Непривлекательно выглядят полученные данные и с позиции качественного анализа ответов на вопросы, характеризующих профессиональную толерантность, преобладают негативные установки в отношении

\section{Baikal Research Journal}

электронный научный журнал Байкальского государственного университета 
будущих коллег, руководства, клиентов, т. е. людей, с которыми придется иметь дело по роду деятельности.

Результаты, полученные по тесту «Эмоциональный интеллект» Н. Холла, представлены на рис. 2.

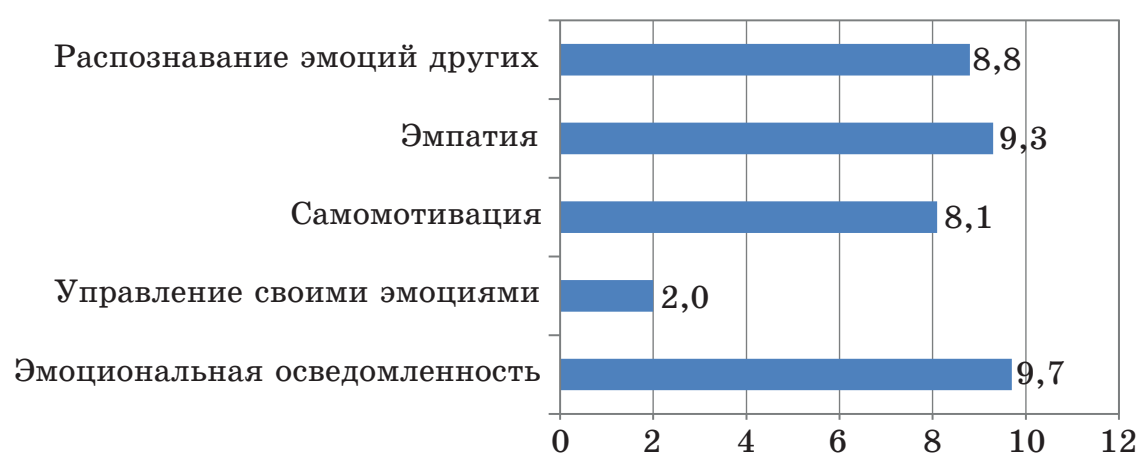

Рис. 2. Средние значения показателей элоционального интеллекта

Анализ полученных данных показывает, что уровни парциального (отдельно по каждой шкале) эмоционального интеллекта в соответствии со знаком результатов находятся в пределах среднего (из пяти шкал четыре шкалы). По средним значениям лидирует шкала «Эмоциональная осведомленность». Средний уровень результатов по ней говорит о том, что респонденты несколько в большей степени пытаются и стараются осознавать, понимать свои эмоции, стремятся пополнять собственный словарь эмоций, имеют среднюю осведомленность о своем внутреннем состоянии. Средний уровень результатов по шкале «Эмпатия», говорит о готовности понимать эмоции и другие проявления невербального поведения других людей, способности сопереживать текущему эмоциональному состоянию другого человека, а так же готовность оказать поддержку.

Из всех показателей эмоционального интеллекта выбивается шкала «Управление своими эмоциями», по ней уровень парциального эмоционально интеллекта крайне низкий. У данной выборки испытуемых этот показатель говорит об эмоциональной негибкости и низком произвольном управлении своими эмоциями, очевидно в силу возраста и отсутствия опыта.

Проявления эмоционального интеллекта имеют значимые различия (или на уровне тенденции) и по половой принадлежности респондентов: по шкале «Управление своими эмоциями» у мужчин и женщин результаты находятся в зоне низкого уровня, но если смотреть средние значения, то более высокие показатели у юношей $(M=4,7 ; p=0,000)$ говорят о том, что они скорее эмоционально отходчивы, имеют эмоциональную гибкость и т. д., другими словами, в большей степени умеют произвольно управлять своими эмоциями, чем девушки $(M=0,5 ; p=0,000)$. Подкрепляют эти выводы и результаты по шкале «Самомотивация»: средние показатели у юношей выше $(M=9,4$, различия достоверны при $p=0,011)$, что говорит о том, что они осознают необходимость управления своим поведением. Высокие показатели по шкале «Эмпатия» у девушек $(M=10,1$; различия достоверны при $p=0,004)$ и по шкале «Распознавание эмоций других" $(M=9,4$; различия достоверны при $p=0,036)$, свидетельствуют о том, что они лучше понимают эмоции других людей и их состояние по мимике, жестам, оттенкам речи, позе; готовы сопереживать эмоциональному состоянию другого человека, а так же более готовы оказать поддержку.

В целом, по общей выборке 51,5 \% респондентов имеют низкий интегративный (сумма по всем шкалам) уровень эмоционального интеллекта, 43,5 \% испы-

\section{Baikal Research Journal}


туемых - средний и только $5 \%$ - высокий. Возможно, это связано с возрастом респондентов и отсутствием у них опыта общения с представителями принципиально иных культур.

Корреляционный анализ (Анализ результатов производился автоматически при помощи программного продукта - SPSS.Ststistics.v22.x64, подсчитывался коэффициент парной корреляции Пирсона) позволил выявить следующие связи:

1. Когнитивный компонент толерантности коррелирует с типами этнической идентичности: чем выше интерес респондентов к мнениям, позициям других людей, тем выше их позитивная этническая идентичность $(0,363 * \%)$ и ниже показатели этноэгоизма (умеренная обратная связь $(-0,378 \%$ ), этноизоляционизма $(-0,252 \% *)$ и этнонигилизма $(-0,250 \% *)$.

2. Межэтническая толерантность имеет положительные связи с позитивной этнической идентичностью $(0,456 * *)$ и этнической индифферентностью $(0,169 * *)$; отрицательные связи со всеми формами гиперидентичности - этноэгоизмом $(-0,518$ **), этноизоляционизмом $(-0,427 * *)$, национальным фанатизмом $(-0,348 * *)$. Таким образом, чем в большей степени проявляется готовность к принятию представителей других этносов, тем выше и позитивное отношение к своему народу, ориентация на аутгруппу и тем менее выражены этноцентризм и ксенофобии.

3. Чем выше уровень толерантности в отношении другой культуры, тем более склонны респонденты к компетентному уверенному поведению $(0,285$ \%*), и обратные связи выявлены с такими элементами перцептивно-коммуникативной компетентности как жестокость в отношениях к людям $(-0,169 * \%)$, брюзжание $(-0,253 * *)$, установки на агрессивное поведение $(-0,294 * \%)$.

4. Шкала эмоционального интеллекта «Эмпатия» коррелирует с толерантным отношением к другому поколению $(0,254 * *)$, а шкала «Распознавание эмоций других» с толерантным отношением к другим $(0,262 \%)$.

В результате процедуры факторного анализа мы проверили составленную нами модель межкультурной компетентности (табл. 4).

Эмпирическая модель межкультурной компетентности (на общей выборке)

\begin{tabular}{|c|c|}
\hline Компонент & Слагаемые компонентов \\
\hline \multirow[t]{5}{*}{ Толерантность } & Другой пол \\
\hline & Отношения с другими \\
\hline & Другая культура \\
\hline & Другое поколение \\
\hline & Другая вера \\
\hline \multirow{4}{*}{$\begin{array}{l}\text { Этническая идентичность } \\
\text { (этническое самосознание) }\end{array}$} & Норма (позитивная этническая идентичность) \\
\hline & Этноизоляционизм \\
\hline & Этноэгоизм \\
\hline & Национальный фанатизм \\
\hline \multirow{5}{*}{$\begin{array}{l}\text { Перцептивно- } \\
\text { коммуникативная } \\
\text { компетентность }\end{array}$} & Распознавание эмоций других \\
\hline & Эмпатия \\
\hline & Невербальная компетентность \\
\hline & Эмоциональная осведомленность \\
\hline & Компетентные коммуникативные умения \\
\hline \multirow[t]{4}{*}{ Апперцептивный } & Брюзжание \\
\hline & Открытая и завуалированная жестокость в отношениях к людям \\
\hline & Негативный личный опыт общения с окружающими \\
\hline & Обоснованный негативизм в суждениях о людях \\
\hline
\end{tabular}

Выделенные компоненты эмпирической модели соотносятся со всеми выделенными нами компонентами теоретической модели.

\section{Baikal Research Journal}


Первый компонент эмпирической модели «Толерантность» входит в когнитивный, аффективный, мотивационный и поведенческий компоненты теоретической модели: виды и шкалы компонентов толерантности. Без этого компонента понятие межкультурной компетентности не представляется возможным: межкультурно компетентный человек - это толерантный человек, который проявляет уважение, терпение по отношению к представителям разных категорий. В модели выделились такие виды толерантности, как гендерная, межличностная, межкультурная, межпоколенная, межконфессиональная (прямые корреляционные связи).

Второй компонент модели связан с этническим самосознанием - это этническая идентичность. Личность, обладающая высоким уровнем межкультурной компетентности характеризуется этнической идентичностью по типу нормы (позитивной этнической идентичностью), ей свойственно предпочтение собственных этнокультурных ценностей и баланс толерантности по отношению к собственной и другим этническим группам (прямая корреляционная связь). Остальные три составляющие компонента относятся к отклонениям от нормы и могут повлиять на уровень развития межкультурной компетентности и ее содержательные характеристики (обратная корреляционная связь).

Третий компонент был обозначен нами, как перцептивно-невербальная компетентность. У человека с высоким уровнем межкультурной компетентности должна быть развита невербальная компетентность, которая поможет ему распознавать, отслеживать, ориентироваться, адекватно интерпретировать невербальные сигналы; высокий уровень эмпатии (умение сопереживать) и коммуникативная компетентность, которая поможет ему использовать компетентные коммуникативные умения (прямые корреляционные связи).

Четвертый блок, на первый взгляд, не вписывается в модель, но факторный анализ включил в один блок эти негативные коммуникативные установки, на формирование которых мог повлиять негативный прошлый опыт коммуникаций и интеракций. Чем меньше эти негативные установки проявятся у человека, тем будет выше межкультурная компетентность (обратные корреляционные связи).

Таким образом, полученные результаты позволяют сделать следующие выводы:

1. В условиях развития современного общества важной составляющей профессиональной подготовки юристов становится межкультурная компетентность, соответственно необходимо скорректировать существующие профессиограммы и психограммы юристов дополнив указанной компетенцией.

2. Анализ полученных в исследовании данных позволяет резюмировать, что респондентов отличает позитивная этническая идентичность, наличие знаний и навыков о специфике общения с представителями иных социальных групп. Наиболее высокий уровень толерантности будущие юристы демонстрируют в отношении другого пола, а самый низкий в отношении представителей другого этноса. Студенты характеризуются средним уровнем перцептивно-невербальной компетентности, ориентацией на уверенное поведение, но среди коммуникативных установок проявляется склонность к жестокости в отношениях к людям, эмоциональная негибкость, низкий уровень самоуправления эмоциями.

3. Эмпирическая модель межкультурной компетентности, выявленная с помощью факторного анализа, включает в себя: толерантность, этническую идентичность (этническое самосознание), перцептивно-коммуникативную компетентность, апперцептивный блок. Характер выявленных взаимосвязей показывает, что коррегирование характеристик вошедших в апперцептивный блок, дает возможность прогнозировать повышение уровня межкультурной компетентности и ее отдельных компонентов.

\section{Baikal Research Journal}

электронный научный журнал Байкальского государственного университета 
4. В учебный процесс целесообразно включить дисциплины, факультативы, либо задания в рамкам существующих предметов, позволяющие формировать межкультурную компетентность будущих специалистов. Вузы, сузы сейчас являются зонами межнациональных, межкультурных и межконфессиональных контактов и этим обязательно нужно воспользоваться в процессе профессиональной подготовки юристов.

\section{Список использованной литературы}

1. Романов В. В. Юридическая психология / В. В. Романов - М. : Юрист, 1998. - 488 с.

2. Карнышев А. Д. Межэтническое взаимодействие и межкультурная компетентность / А. Д. Карнышев, М. А. Винокуров, Е. Л. Трофимова. - Иркутск : Изд-во БГУЭП, 2009. -310 c.

3. Карнышев А. Д. Личность и межкультурная компетентность / А. Д. Карнышев // Психология в экономике и управлении. - 2009. - № 2. - С. 99-106.

4. Психология межкультурной компетентности: сущность, региональная специфика, технологии формирования / А. Д. Карнышев, Т. А. Терехова, Е. Л. Трофимова [и др.]. Иркутск : Репроцентр A1, 2012. - 438 с.

5. Трофимова Е. Л. Формирование готовности к межкультурному сотрудничеству у студентов в процессе обучения и воспитания в вузе / Е. Л. Трофимова // Сибирский психологический журнал. - 2013. - № 47. - С. 129-140.

6. Васильева Н. Н. Межкультурная компетенция. Стратегии и техники ее достижения [Электронный ресурс] / Н. Н. Васильева. - Режим доступа: //http://rspu.edu.ru/ iournals/lexicography/ conference/vasilieva\% 20N.htm.

7. Купавская А. С. Развитие этнокультурной компетентности подростка методом социально-психологического тренинга : автореф. дис. ... канд. психол. наук : 19.00.05 / А. С. Купавская. - М., 2008. - 26 с.

8. Леонтович О. А. Россия и США. Введение в межкультурную коммуникацию / О. А. Леонтович. - Волгоград : Перемена, 2003. - 399 с.

9. Новицкая А. В. Формирование межкультурной компетенции в различных видах межкультурных контактов / А. В. Новицкая // Сборник научных трудов Северо-Кавказского государственного технического университета. - Ставрополь : Изд-во Сев.-Кавк. гос. техн. ун-та, 2008. - Вып. 6. - С. 211-221. - (Гуманитарные науки).

10. Поштарева Т. В. Формирование этнокультурной компетентности / Т. В. Поштарева // Педагогика. - 2005. - № 3. - С. 35-42.

11. Поштарева Т. В. Формирование этнокультурной компетентности учащихся в полиэтнической образовательной среде : автореф. дис. ... д-ра пед. наук : 13.00 .01 / Т. В. Поштарева. - Владикавказ, 2009. - 40 с.

12. Садохин А. П. Введение в теорию межкультурной коммуникации / А. П. Садохин. - М. : Высш. шк., 2005. - 310 с.

13. Психодиагностика толерантности личности / Г. У. Солдатова, Л. А. Шайгерова, Т. Ю. Прокофьева, О. А. Кравцова. - М. : Смысл, 2008. - 172 с.

14. Fischer G. E-mail in foreign language teaching. Towards the creation of virtual classrooms / G. Fischer. - Tbbingen, Germany : Stauffenburg Medien, 1998. - 77 p.

15. Knapp K. Intercultural Communication in EESE [Electronic resource] / K. Knapp. Mode of access: http://www.cs.uu.nl/docs/vakken/bci/programma/intercult.html.

16. Большакова О. Б. Отечественные концептуальные модели межкультурной компетентности / О. Б. Большакова, Т. А. Терехова // Психология в экономике и управлении. 2011. - № 1. - C. 93-105.

17. Большакова О. Б. Зарубежные концептуальные модели межкультурной компетентности / О. Б. Большакова, Т. А. Терехова // Психология в экономике и управлении. 2011. - № 1. - C. 84-96.

18. Терехова Т. А. Психологические факторы устойчивости культуры бурят-шаманистов / T. А. Терехова // Явные и скрытые смыслы культурной коммуникации = Explicit and Implicit meanings of cultural communication / T. А. Терехова, С. К. Малахаева. - Гнезно : Ин-т европ. культуры, 2015. - Т. 2. - С. 41-52.

\section{Baikal Research Journal}


19. Трофимова Е. Л. Возможности использования метафоры в формировании межкультурной компетентности / Е. Л. Трофимова, Т. А. Терехова // Известия Иркутской государственной экономической академии. - 2015. - T. 25, № 4. - С. 708-716. - DOI: 10.17150/1993-3541.2015.25(4).708-716.

20. Наролина В. И. Межкультурная коммуникативная компетентность как интегративная способность межкультурного общения специалиста [Электронный ресурс] / В. И. Наролина // Психологическая наука и образование. - 2010. - № 2. - Режим доступа: http://www.psyedu.ru.

21. Птицына И. Ф. Педагогические условия формирования межкультурной компетенции вторичной языковой личности студентов (на материале изучения японского языка и культуры) : автореф. дис. ... канд. пед. наук : 13.00.01 / И. Ф. Птицына. - Якутск, 2008. -25 c.

\section{References}

1. Romanov V. V. Yuridicheskaya psikhologiya [Juridical Psychology]. Moscow, Yurist Publ., 1998. 488 p.

2. Karnyshev A. D., Vinokurov M. A., Trofimova E. L. Mezhetnicheskoe vzaimodeistvie $i$ mezhkul'turnaya kompetentnost' [Cross-ethnic Interaction and Intercultural Competence]. Irkutsk, Baikal State University of Economics and Law Publ., 2009. 310 p.

3. Karnyshev A. D. Personality and cross-cultural competence. Psikhologiya v ekonomike $i$ upravlenii $=$ Psychology in Economics and Management, 2009, no. 2, pp. 99-106. (In Russian).

4. Karnyshev A. D., Terekhova T. A., Trofimova Ye. L. et al. Psikhologiya mezhkul'turnoi kompetentnosti: sushchnost', regional'naya spetsifika, tekhnologii formirovaniya [Cross-cultural Competence Psychology: Essence, Regional Specifics, Development Technology]. Irkutsk, Reprotsentr A1 Publ., 2012. 438 p.

5. Trofimova Ye. L. Developing students' readiness for cross-cultural cooperation in the course of university training and education. Sibirskii psikhologicheskii zhurnal = Siberian Psychological Journal, 2013, no. 47, pp. 129-140. (In Russian).

6. Vasilyeva N. N. Mezhkul'turnaya kompetentsiya. Strategii i tekhniki ee dostizheniya [Cross-cultural competence. Strategies and technologies of its implementation]. Available at: http://rspu.edu.ru/iournals/lexicography/ conference/vasilieva\% 20N.htm. (In Russian).

7. Kupavskaya A. S. Razvitie etnokul'turnoi kompetentnosti podrostka metodom sotsial'no-psik hologicheskogo treninga. Avtoref. Kand. Diss. [Developing teenager's cross-cultural competence through socio-psychological training method. Cand. Diss. Thesis]. Moscow, 2008. 26 p.

8. Leontovich O. A. Rossiya i SShA. Vvedenie v mezhkul'turnuyu kommunikatsiyu [Russia and the USA. Introduction into cross-cultural competence]. Volgograd, Peremena Publ., 2003. $399 \mathrm{p}$.

9. Novitskaya A. V. Developing ethno-cultural competence in various types of cross-cultural contacts. Sbornik nauchnykh trudov Severo-Kavkazskogo gosudarstvennogo tekhnicheskogo universiteta. Seriya: Gumanitarnye nauki [Collection of Scientific Works of North Caucasian State Technical University. Humanities Series]. Stavropol, North Caucasian State Technical University Publ., 2008, iss. 6, pp. 211-221. (In Russian).

10. Poshtareva T. V. Developing ethno-cultural competence. Pedagogika = Pedagogics, 2005, no. 3, pp. 35-42. (In Russian).

11. Poshtareva T. V. Formirovanie etnokul'turnoi kompetentnosti uchashchikhsya $v$ polietnicheskoi obrazovatel'noi srede. Avtoref. Dokt. Diss. [Developing students' ethno-cultural competence in poly-ethnic educational environment. Doct. Diss. Thesis]. Vladikavkaz, 2009. 40 p.

12. Sadokhin A. P. Vvedenie $v$ teoriyu mezhkul'turnoi kommunikatsii [Introduction into Theory of Cross-Cultural Competence]. Moscow, Vysshaya shkola Publ., 2005. 310 p.

13. Soldatova G. U., Shaigerova L. A., Prokof'eva T. Yu., Kravtsova O. A. Psikhodiagnostika tolerantnosti lichnosti [Psycho-diagnosis of personal tolerance ]. Moscow, Smysl Publ., 2008. $172 \mathrm{p}$.

14. Fischer G. E-Mail in Foreign Language Teaching. Towards the Creation of Virtual Classrooms. Tьbingen, Germany, Stauffenburg Medien, 1998. 77 p.

15. Knapp K. Intercultural Communication in EESE. Available at: http://www.cs.uu.nl/ docs/vakken/bci/programma/intercult.html.

\section{Baikal Research Journal}

электронный научный журнал Байкальского государственного университета 
16. Bolshakova O. B., Terekhova T. A. National conceptual models of cross-cultural competence. Psikhologiya $v$ ekonomike $i$ upravlenii = Psychology in Economics and Management, 2011, no. 1, pp. 93-105. (In Russian).

17. Bolshakova O. B., Terekhova T. A. Foreign conceptual models of cross-cultural competence. Psikhologiya $v$ ekonomike $i$ upravlenii = Psychology in Economics and Management, 2011, no. 1, pp. 84-96. (In Russian).

18. Terekhova T. A. Psychological factors of cultural stability of Buryat-shamans. In Terekhova T. A., Malakhayeva S. K. Yavnye i skrytye smysly kul'turnoi kommunikatsii [Explicit and Implicit Meanings of Cultural Communication]. Gnezno, Institute of European Culture Publ., 2015, vol. 2, pp. 41-52.

19. Trofimova Ye. L., Terekhova T. A. The metaphor as a way of cross-cultural competence development. Izvestiya Irkutskoi gosudarstvennoi ekonomicheskoyi akademii = Bulletin of Irkutsk State Economics Academy, 2015, vol. 25, no. 4, pp. 708-716. DOI: 10.17150/19933541.2015.25(4).708-716. (In Russian).

20. Narolina V. I. Cross-cultural communicative competence as an integrative ability of specialist's cross-cultural communication competence. Psikhologicheskaya nauka i obrazovanie = Psychological Science and Education, 2010, no. 3. Available at: http://www.psyedu. ru. (In Russian).

21. Ptitsyna I. F. Pedagogicheskie usloviya formirovaniya mezhkul'turnoi kompetentsii vtorichnoi yazykovoi lichnosti studentov ( na materiale izucheniya yaponskogo yazyka i kul'tury). Avtoref. Kand. Diss. Pedagogical environment for developing cross-cultural competence of secondary students' language personality (in terms of studying the Japanese language and culture). Cand. Diss. Thesis]. Yakutsk, 2008. 25 p.

\section{Информация об авторе}

Трофилова Елена Леонидовна - кандидат психологических наук, доцент, кафедра социальной и экономической психологии, социологии и социальной работы, Байкальский государственный университет, 664003, г. Иркутск, ул. Ленина, 11, e-mail: trofimovabgy@mail.ru.

Черёмухина Кристина Сергеевна - старший преподаватель, кафедра социальной и экономической психологии, социологии и социальной работы, Байкальский государственный университет, 664003, г. Иркутск, ул. Ленина, 11, e-mail: kristall923@mail.ru.

\section{Authors}

Elena L. Trofimova - PhD in Psychology, Associate Professor, Chair of Social and Economic Psychology, Sociology and Social Work, Baikal State University, 11 Lenin St., 664003, Irkutsk, Russian Federation; e-mail: trofimova-bgy@mail.ru.

Kristina S. Cheremukhina - Senior Lecturer, Chair of Social and Economic Psychology, Sociology and Social Work, Baikal State University, 11 Lenin St., 664003, Irkutsk, Russian Federation; e-mail: kristall923@mail.ru.

\section{Библиографическое описание статьи}

Трофимова Е. Л. Межкультурная компетентность как необходимая составляющая профессиональной подготовки юристов / Е. Л. Трофимова, К. С. Черёмухина // Baikal Research Journal. - 2017. — T. 8, № 2. — DOI: 10.17150/2411-6262.2017.8(2).35.

\section{Reference to article}

Trofimova E. L., Cheremukhina K. S. Cross-cultural competence as a necessary constituent of professional training lawyers. Baikal Research Journal, 2017, vol. 8, no. 2. DOI: 10.17150/2411-6262.2017.8(2).35. (In Russian).

\section{Baikal Research Journal}

